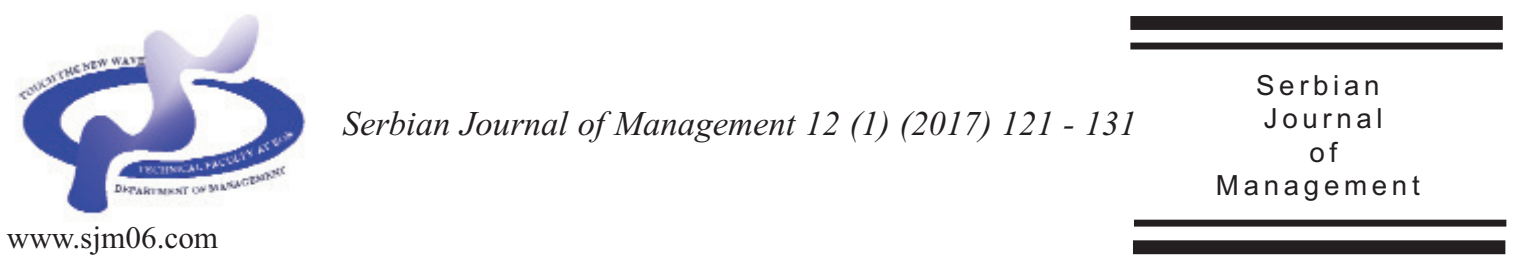

\title{
EMPIRICAL RESULTS OF ENTREPRENEURS' NETWORK: CASE STUDY OF SLOVAKIA
}

\author{
Ladislav Mura ${ }^{a^{*}}$, Katarína Haviernikováb and Renáta Machovác \\ a Pan-European University in Bratislava, Faculty of Economics and Business, Department \\ of International Entrepreneurship, Tematínska 10, 85105 Bratislava, Slovak Republic

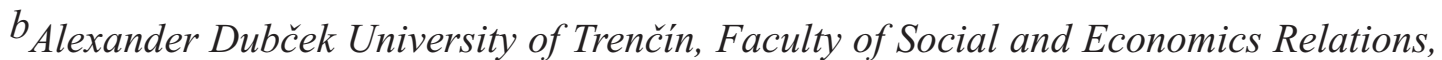 \\ Department of Economy and Economics, Študenstká 3, 91150 Trenčin, Slovak Republic \\ c J. Selye University, Faculty of Economics, Department of Management, Bratislavská \\ cesta 3322, 94501 Komárno, Slovak Republic
}

(Received 3 March 2016; accepted 25 November 2016)

\begin{abstract}
The changes in economic development of different countries in recent decades are influenced by processes that have modified the ways and forms of doing business. While in the past, the emphasis was put on size of the company, currently its participation in various forms of network cooperation prevails. The following paper presents results of empirical research realized between the small and medium sized enterprises involved into entrepreneurs' networks. Research was conducted during the period $2014-2015$ in a frame of scientific research project VEGA 1/0381/13 and KEGA 001UCM$4 / 2016$.

The main aim of paper is to propose the basic model of network entrepreneurial cooperation in the conditions of the Slovak republic. The novelty of this paper is to mention the main steps that should be done by stakeholders, if they want to create successful network. The partial aims of this paper are: the evaluation of quantitative and qualitative conditions for networking and description of partial steps which lead to creation of network cooperation. Celected quantitative methods were used (Localization coefficient with combination of BCG matrix). Qualitative conditions were evaluated through the results of questionnaire survey, which identified the entrepreneurs' suggestions for the business to be engaged into the network (by using Pearson chi-square, Kruskal Wallis and Median Tests).
\end{abstract}

Keywords: Networking, entrepreneurs' network, innovative entrepreneurship, small and medium sized enterprises

* Corresponding author: ladislav.mura@gmail.com

DOI: $10.5937 /$ sjm12-10418 


\section{INTRODUCTION}

The issue of entrepreneurs' networking is possible to define as a group of several entities that come into interactions based on different forms of agreements in order to gain a comparative advantage over other entities simultaneously on two levels: the entity itself and the level of the whole network. Different forms of networking will not fulfill a role within the overall replacement of the company but complemented and developed the activities of companies. The internal coordination of companies' processes is in their competence. For involved entities the substantial results are effects which result from their participation in the network. These effects can be both positive, as well as negative with different level of impact on the overall performance of the network. An important prerequisite for network cooperation creation in region is the structure of its economy according the business entities and branches. It is important to analyze factors influencing the decline of sole proprietorship type of companies and if new emerging capital micro-companies are more successful due to their type of business. The economic activities of Slovak small and medium sized enterprises are of a great benefit to economic and social development of both regions and national economy of the country (Š́bertová, 2015; Buleca, 2013).

According Habánik and Masárová (2001), the branch structure breaks the national economy into branches that create the companies with the same or similar orientation. The state should create favorable conditions for the formation and influencing the structure of economy. The effects of various factors, driving sources and processes at the micro and macro level and achieving significant effects, means the entrepreneurs' network cooperation acquires new dimension and deserves further attention and clarification.

\section{MATERIAL AND METHODS}

Using localization methods we evaluate the quantitative conditions for network cooperation in Slovak regions. In accordance of their results we identified the key regions with prevailing branches. The paper describes the analysis that is carried out by means of localization coefficient - LQ. The localization coefficient compares the characteristics of a sector at regional and higher (national, transnational) level. LQ expresses which industries prevails in the region.

A calculation for LQ defines the relation:

LQiyr $=(z i / z) /(Z i / Z)$

where: LQi,y,r (LQ) L o c a 1 i z a t i o $n$ coefficient for the branch - i,

$\mathrm{y}$ - year,

r-region,

zi - number of employees in the branch, in the region,

$\mathrm{Z}$ - total number of employees in region,

$\mathrm{Zi}$ - number of employees in branch at national level,

$\mathrm{Z}$ - total number of employees at national level.

The value LQ higher than 1 shows the regional specialization, it means that the given branch employs people that have larger share in the regional labour force than they are at the level of region. The value LQ below 1 means reverse.

The values obtained from the calculation 
of LQi,y,r are incorporated into the BCG matrix, based on which we have identified the sectors important for the network creation and operation in the region.

While the calculation of LQi,y,r gives a static picture of an individual branch in a region, the BCG matrix takes into account the effect of time exposure and point on the dynamism of the regional specialization. Despite certain limitations the BCG matrix in this context is often used in various studies regarding the identification of prevailing branches in a region, as well as the potential of region for network cooperation creation, mainly in an area of clustering (Waldorf et al., 2006; Zaušková, 2010; Bujna et al., 2014; Chen et al., 2013; Kołakowski \& Sobański, 2013).

The BCG matrix consists of two parameters: the value of LQi,y,r in branch (i) and specific year (y) calculated for region (r) and the percentage change from calculation of LQi,y,r through two compared periods $(\Delta \mathrm{LQi}, \mathrm{y}, \mathrm{r})$. Subsequently, the data are recorded into the BCG matrix thereby the branches are broken down into four types: STARS, MATURE, EMERGING and TRANSFORMING. Each type fulfills a different role in local or regional economy and thus requires different development activities. STARS: The branches/regions are defined as sectoral clusters with high and positive level of LQ, which is increasing over time. The branches/regions have highly attractive market share, even assuming their further progress. It is recommended to let the branches/regions continue to carry out their activities and promote them for a further. In this quadrant are also branches/regions where the potential for network (clusters) creation exist. MATURE: these branches/regions are classified as "mature", with a high level of LQ, but with a declining trend with its negative value measured by $\triangle \mathrm{LQ}$. It is recommended to direct the development policy towards promotion of these branches/regions with the aim to progressively move them towards the sector STARS.

EMERGING: In this sector we can find the branches/regions that have a low, but increasing level of LQ measured by $\triangle \mathrm{LQ}$. Development policy should be directed towards maintaining or promoting the growth of branches/region, if the sector growth as well as national level, so as to convert them into the STARS, or if there is a further decline of LQ, it is necessary to move them into the quadrant TRANSORMING.

TRANFORMING: presents the branches/regions with very low level of power (low level of LQ and falling level of $\Delta \mathrm{LQ})$. It is recommended to either maintain the branch, but without significant support (which may lead to downfall), or promote the branch if it has local significance or is important for another branch. The data used for calculation of LQ in the observed period (years 2010, 2014) were obtained from regional statistics database of the Statistical office of the Slovak Republic. For calculation of LQ, the data of average registered number of employees were used.

In order to meet main aim stated, we used for explanation the results of questionnaire survey. For evaluation the following statistical methods were used: Pearson Chi Square test, Kruskal-Wallis test and Median test. These methods were applicate by using the statistical software STATISTICA. According notes of program Statistica: the Pearson Chi-square is the most common test for significance of the relationship between categorical variables. This measure is based on the fact that we can compute the expected frequencies in a two-way table (i.e., 
frequencies that we would expect if there was no relationship between the variables).

The Kruskal-Wallis ANOVA by Ranks test assumes that the variable under consideration is continuous and that it was measured on at least an ordinal (rank order) scale. The test assesses the hypothesis that the different samples in the comparison were drawn from the same distribution or from distributions with the same median.

The Median test is a "crude" version of the Kruskal-Wallis ANOVA in that it frames the computation in terms of a contingency table. Specifically, STATISTICA will simply count the number of cases in each sample that fall above or below the common median, and compute the Chi-square value for the resulting $2 \mathrm{x} \mathrm{k}$ samples contingency table. Under the null hypothesis (all samples come from populations with identical medians), we expect approximately $50 \%$ of all cases in each sample to fall above (or below) the common median.

\section{RESULTS}

In the frame of scientific research project VEGA 1/0381/13 and KEGA 001UCM$4 / 2016$ the pilot questionnaire survey of the basic conditions of network cooperation in the business environment was carried out. Based on the results of questionnaire survey and in light of other domestic and international research works (Fiala, 2008; Tidd et al., 2005; Vojtovic \& Krajnakova, 2013; Grenčíková et al., 2015; Okreglická et al., 2015; Krajnakova et al., 2015; Belás et al., 2015; Živković et al., 2009) from the areas of networking and regional economy, the basic model of network entrepreneurial cooperation was designed by authors. The structure of this part of the paper is the following: Step 1st: we calculated the value of LQ for years 2010 and 2014 for branches of Slovak economy where the data were available. The LQs were calculated for each of 8 Slovak regions: BA Bratislava, TT Trnava, TN Trenčín, NR Nitra, ZA Žilina, BB Banská Bystrica, PO Prešov, KE Košice. We evaluated branches: A Agriculture, C Manufacturing, D Electricity gas steam and air conditioning supply, E Water supply, F Construction, G Wholesale and retail trade, $\mathrm{H}$ transportation and storage, I Accommodation and food service activities, $\mathrm{K}$ Financial and insurance activities, M Professional, scientific and technical activities, $\mathrm{N}$ Administrative and support service activities, O Public administration and defense, P Education, Q Human health and work activities, R Art, entertainment and recreation, $\mathrm{S}$ Other service activities. The results of $\mathrm{LQ}_{2014}$ are presenting in table 1 . The value of $L_{2014}>1$ pointed out the prevailing branches in Slovak regions. We stated as a significant value of $\mathrm{LQ}_{2014}$ the value higher than 1,20. In the light of results of Waldorf et al. (2006), Loučanová and Zaušková (2007), Zaušková (2010), Chen et al. (2013), Kołakowski and Sobański (2013) we can conclude, that in branches where $\mathrm{LQ}_{2014}>1,20$ in the Slovak regions, the potential for networking exists.

Step 2nd: from the results of $\mathrm{LQ}_{2014}$ and $\mathrm{LQ}_{2010}$ the $\triangle \mathrm{LQ}(\%)$ was calculated. According these results the following analysis in article is focused on 3 prevailing branches: A, I, C. Step 3rd: From results of $\mathrm{LQ}_{2014}$ and $\triangle \mathrm{LQ}(\%)$ the BCG matrixes for prevailing industries were constructed (Figure 1-3).

BCG matrixes of specialization for branches C, I, A in Slovak regions in sector STARS indicate which regions are 
Table 1. The results of $L Q$ (2014)

\begin{tabular}{|c|c|c|c|c|c|c|c|c|}
\hline Branch & BA & TT & TN & NR & $\mathbf{Z A}$ & BB & PO & KE \\
\hline $\mathbf{A}$ & 0.10 & 2.51 & 1.54 & 1.71 & 0.94 & 1.88 & 1.20 & 0.37 \\
\hline C & 0.40 & 1.46 & 1.79 & 1.42 & 1.30 & 0.91 & 1.03 & 1.04 \\
\hline D & 1.70 & 0.32 & 0.29 & 0.19 & 1.15 & 0.37 & 0.95 & 1.35 \\
\hline $\mathbf{E}$ & 0.42 & 0.41 & 0.91 & 1.28 & 1.04 & 2.57 & 0.71 & 1.71 \\
\hline F & 0.90 & 0.83 & 0.47 & 1.13 & 1.99 & 0.44 & 1.07 & 1.39 \\
\hline G & 1.48 & 0.89 & 0.85 & 0.81 & 0.86 & 0.66 & 0.93 & 0.51 \\
\hline $\mathbf{H}$ & 1.64 & 0.41 & 0.40 & 0.48 & 0.56 & 2.07 & 0.42 & 0.49 \\
\hline I & 1.28 & 1.43 & 1.35 & 0.02 & 0.81 & 0.2 & 1.61 & 0.77 \\
\hline $\mathbf{K}$ & 2.92 & 0.13 & 0.02 & 0.02 & 0.28 & 0.02 & 0.16 & 0.14 \\
\hline M & 2.10 & 0.92 & 0.40 & 0.35 & 0.38 & 0.49 & 0.24 & 0.64 \\
\hline $\mathbf{N}$ & 1.40 & 0.94 & 0.95 & 0.87 & 0.42 & 0.40 & 1.07 & 1.08 \\
\hline $\mathbf{O}$ & 1.40 & 0.69 & 0.55 & 0.79 & 0.69 & 1.18 & 0.98 & 0.84 \\
\hline $\mathbf{P}$ & 0.51 & 1.07 & 0.89 & 1.24 & 1.32 & 1.12 & 1.62 & 1.37 \\
\hline $\mathbf{Q}$ & 0.62 & 1.10 & 0.86 & 0.98 & 1.26 & 1.06 & 1.45 & 1.50 \\
\hline $\mathbf{R}$ & 1.44 & 0.63 & 0.45 & 0.71 & 1.15 & 1.07 & 0.71 & 0.83 \\
\hline $\mathbf{S}$ & 1.23 & 0.76 & 0.22 & 1.11 & 0.65 & 0.47 & 1.20 & 1.84 \\
\hline
\end{tabular}

Source: Own elaboration based on data of average registered number of employees

considered as successful localities of corresponding branches. The regions which are in sectors TRANSFORMING and EMERGING show lower specializations of the stated branch in these regions.

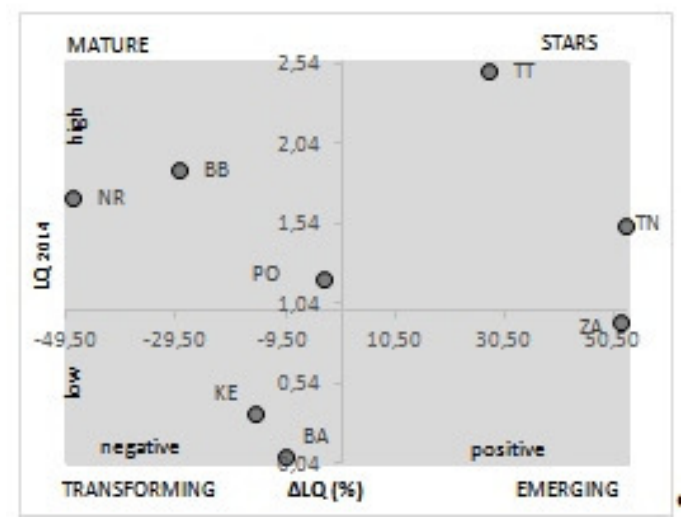

Source: Own elaboration

Figure 1. BCG matrix of specialization in the branch of agricultural

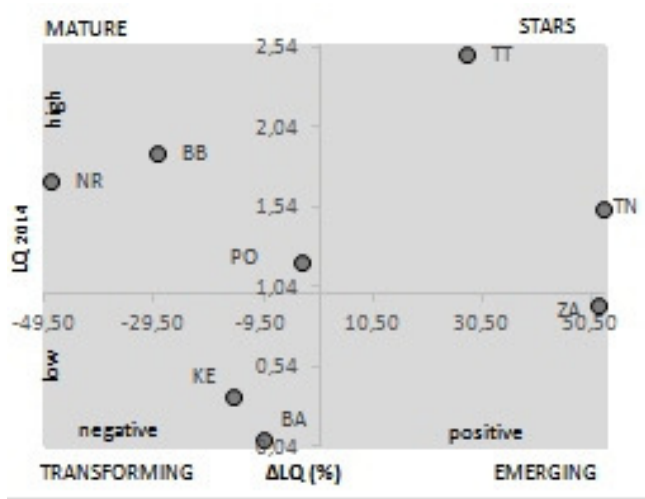

Source: Own elaboration

Figure 2. BCG matrix of specialization in the branch of manufacturing

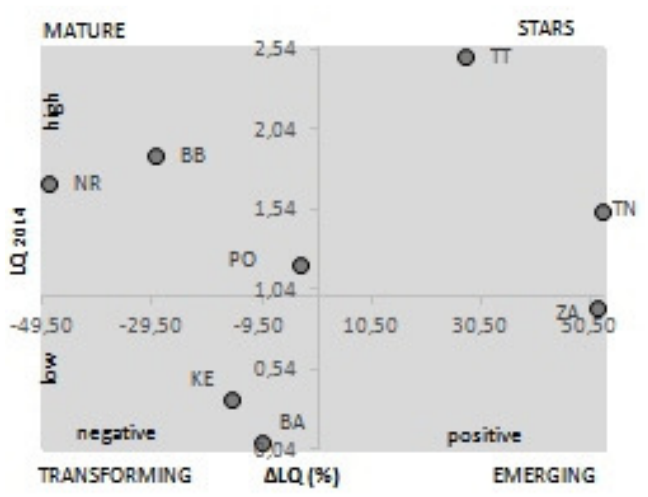

Source: Own elaboration

Figure 3. BCG matrix of specialization in the branch of services

Step $4^{\text {th: }}$ In this step we started the process of questionnaire results treatment. In accordance of LQs' results we focused on respondents from three branches of national economy, which prevail in Slovakia and have experience from participation in network cooperation. For this study we randomly selected a total of 81 entities from the Slovak regions, of which $49 \%$ was from branch $\mathrm{C}$, $20 \%$ of I and $31 \%$ of A. The legal forms of these entities are: self-employed persons (17\%), Ltd. companies (63\%), joint stock companies (20\%). In this paper we set out 2 scientific hypotheses by the method of expert 
estimation for selected questions. First hypothesis $\mathrm{H}_{1}$ : there is no difference between the opinions of companies from stated branches on the effects of network cooperation. This hypothesis was set out for questions: Q1 - Which reasons are important for connection to the network? Q2 - Which positive aspects arising from participation in network cooperation with entities from the same branch? Q3 - Which negative aspects arising from participation in network cooperation with entities from the same branch? Q4 - which positive aspects arising from participation in network cooperation with competitors?

Statistically significant differences between the branches were compared through Pearson chi square test and Median test at significance level of $5 \%$. If the calculated p-value is lower than 0.05 we reject the $\mathrm{HO}_{1}$ and the alternative hypothesis $\mathrm{H} 1_{1}$ was adopted. Respondents' answers to Q1 present table 2.

As we can see, respondents could choose from 6 reasons: 1 the strategy of common entrepreneurs' activities, 2 management of common entrepreneurs' activities, 3 risk

Table 2. Q1 Which reasons are important for connection to the network

\begin{tabular}{cccc}
\hline Reasons & $\mathbf{C}$ & $\mathbf{I}$ & $\mathbf{A}$ \\
\hline $\mathbf{1}$ & $33.33 \%$ & $25.00 \%$ & $41.67 \%$ \\
$\mathbf{2}$ & $60.00 \%$ & $26.67 \%$ & $13.33 \%$ \\
$\mathbf{3}$ & $100.00 \%$ & $0.00 \%$ & $0.00 \%$ \\
$\mathbf{4}$ & $37.50 \%$ & $25.00 \%$ & $37.50 \%$ \\
$\mathbf{5}$ & $58.33 \%$ & $20.83 \%$ & $20.83 \%$ \\
$\mathbf{6}$ & $44.44 \%$ & $11.11 \%$ & $44.44 \%$ \\
\hline
\end{tabular}

Pearson chi-sq. : 23.2129, df=10. p=.009988

Source: Own elaboration management, 4 cost sharing, 5 new business impulses, 6 the commercialization of innovative idea. Reason 1 is the most important for $41.67 \%$ of entrepreneurs from branch A, reason 2 for entrepreneurs from C $(60 \%)$, reason 3 is important only for $\mathrm{C}$ $(100 \%)$, and reason 4 is equally important for $\mathrm{C}$ and $\mathrm{A}(37.5 \%), 5$ for $\mathrm{C}(58.33 \%)$ and 6 is equally important for $\mathrm{C}$ and $\mathrm{A}(44.44 \%)$. The results of Pearson chi square shows, that.

For a given value of Pearson $\mathrm{chi}^{2}=23.21$ $\mathrm{df}=10$, and at the alpha $=0.05$ the probability of getting a chi ${ }^{2}$ value to be equal or less than 3.94 to have this as a significant difference. We Reject $\mathrm{HO}_{1}$ and accept alternative hypothesis $\mathrm{H}_{1}$ that between the opinions of companies from stated branches on the effects of network cooperation is significant difference.

The answers of respondents according Q2 presented table 3.

Respondents could choose from 7 positives. Following positives are most important for branch A: 1 innovations and dynamic progress $(75.00 \%) 2$ effectiveness

Table 3. Q2 - Which positive aspects arising from participation in network cooperation with entities from the same branch?

\begin{tabular}{cccc}
\hline Positives & C & I & A \\
\hline $\mathbf{1}$ & $25.00 \%$ & $0.00 \%$ & $75.00 \%$ \\
$\mathbf{2}$ & $12.50 \%$ & $12.50 \%$ & $75.00 \%$ \\
$\mathbf{3}$ & $21.43 \%$ & $14.29 \%$ & $64.29 \%$ \\
$\mathbf{4}$ & $19.05 \%$ & $38.10 \%$ & $42.86 \%$ \\
$\mathbf{5}$ & $33.33 \%$ & $66.67 \%$ & $0.00 \%$ \\
$\mathbf{6}$ & $77.78 \%$ & $22.22 \%$ & $0.00 \%$ \\
$\mathbf{7}$ & $30.00 \%$ & $25.00 \%$ & $45.00 \%$ \\
\hline
\end{tabular}

Pearson chi-sq.: $31.7310, \mathrm{df}=14 . \mathrm{p}=.004374$

Source: own elaboration 
$(75.00 \%) 3$ increasing of competitiveness (64.29\%), 4 higher investment and better financial possibilities $42.86 \%$ ) and the reason of 7 th positive - overall cost reduction (45\%). The reasons 5 Research \& Development that is important for branch I (66.67\%) and last positive - 6 mutual cooperation is the most important for entities from branch $\mathrm{C}(77.78 \%)$.

The answers of respondents for Q3 are presented in table 4. From the results of Pearson chi-sq. $=31.73 \mathrm{df}=14, \mathrm{p}=.004374$ follow, that we have to reject $\mathrm{H} 0_{1}$ and accept alternative hypothesis $\mathrm{H} 1_{1}$.

Table 4. Q3 - Which negative aspects arising from participation in network cooperation with entities from the same branch?

\begin{tabular}{cccc}
\hline Negatives & $\mathbf{C}$ & $\mathbf{I}$ & $\mathbf{A}$ \\
\hline $\mathbf{1}$ & $34.88 \%$ & $23.26 \%$ & $41.86 \%$ \\
$\mathbf{2}$ & $28.57 \%$ & $28.57 \%$ & $42.86 \%$ \\
$\mathbf{3}$ & $60.00 \%$ & $40.00 \%$ & $0.00 \%$ \\
$\mathbf{4}$ & $25.81 \%$ & $25.81 \%$ & $48.39 \%$ \\
$\mathbf{5}$ & $33.33 \%$ & $66.67 \%$ & $0.00 \%$ \\
$\mathbf{6}$ & $12.20 \%$ & $14.63 \%$ & $73.17 \%$ \\
\hline
\end{tabular}

Pearson chi-sq.: 24.1231, df=10. p=.007280

Source: own elaboration

Q3 consists of possibilities: 1 the reduction of company's competitiveness, 2 financial losses, 3 higher costs, 4 loss of sovereignty, 5 reductions of jobs, 6 there are not any negatives. The negatives 1, 2, 4, 6 are mostly significant for branch $A$, the $3^{\text {rd }}$ negative aspect was marked by $60 \%$ of respondents in branch $\mathrm{C}$. The $5^{\text {th }}$ negative arises from network cooperation mainly for respondents from branch I. As we can see from results of Pearson chi-sq.: 24.12, df $=10$, $\mathrm{p}=, 007280$, we have to reject the H01 and adopt the alternative hypothesis $\mathrm{H} 1_{1}$.

The results for Q4 presented table 5 and consists of possibilities: 1 cooperation, 2 new knowledge, 3 new jobs, 4 financial savings, 5 new customers, 6 profit share, 7 there are not any positives. From point of view positive aspects of cooperation with competitors, we can observe that they are most important for respondents from branch A. As follows from results in table 5, for the entrepreneurs in branch $\mathrm{C}$ the cooperation with competitors is not very significant.

Table 5. Q4 - which positive aspects arising from participation in network cooperation with competitors?

\begin{tabular}{cccc}
\hline Negatives & C & I & A \\
\hline $\mathbf{1}$ & $31.58 \%$ & $52.63 \%$ & $15.79 \%$ \\
$\mathbf{2}$ & $31.82 \%$ & $0.00 \%$ & $68.18 \%$ \\
$\mathbf{3}$ & $22.64 \%$ & $15.09 \%$ & $62.26 \%$ \\
$\mathbf{4}$ & $33.33 \%$ & $66.67 \%$ & $0.00 \%$ \\
$\mathbf{5}$ & $36.36 \%$ & $36.36 \%$ & $27.27 \%$ \\
$\mathbf{6}$ & $30.00 \%$ & $10.00 \%$ & $60.00 \%$ \\
$\mathbf{7}$ & $0.00 \%$ & $25.00 \%$ & $75.00 \%$ \\
\hline \multirow{2}{*}{ Pearson chi-sq.: $36.4789, \mathrm{df}=12, \mathrm{p}=.000271$} \\
\multicolumn{3}{l}{ Source: own elaboration }
\end{tabular}

According results of Pearson chi-sq.: $36.48, \mathrm{df}=12, \mathrm{p}=.000271$, we have to reject the $\mathrm{HO}_{1}$ and adopt the alternative hypothesis $\mathrm{H} 1_{1}$.

The second $\mathrm{HO}_{2}$ hypothesis was set as follows: the branch has no impact on the factors that will keep the company competitive. This hypothesis was set out for question Q5- Which factors mainly influenced the competitiveness of companies? (1 - irrelevant, 5 - very 
important). For evaluation of this question we used non-parametric multi-selective Kruskal Wallis Test and Median test. The results presents table 6 .

Table 6. The key factors of competitiveness

\begin{tabular}{|c|c|c|}
\hline $\mathbf{F}$ & Test & Results \\
\hline \multirow{2}{*}{1} & $\mathrm{~K}-\mathrm{W}$ Test & $\mathrm{H}(2, \mathrm{~N}=81)=.999 \mathrm{p}=.6069$ \\
\hline & Median test & Chi-Sq. $=.586 \mathrm{df}=2 \mathrm{p}=.7462$ \\
\hline \multirow{2}{*}{2} & $\mathrm{~K}-\mathrm{W}$ Test & $\mathrm{H}(2, \mathrm{~N}=81)=.852 \mathrm{p}=.6530$ \\
\hline & Median test & Chi-Sq. $=.874 \mathrm{df}=2 \mathrm{p}=.6459$ \\
\hline \multirow{2}{*}{3} & $\mathrm{~K}-\mathrm{W}$ Test & $\mathrm{H}(2, \mathrm{~N}=81)=2.758 \mathrm{p}=.2518$ \\
\hline & Median test & Chi-Sq. $=1.066 \mathrm{df}=2 \mathrm{p}=.5869$ \\
\hline \multirow{2}{*}{4} & $\mathrm{~K}-\mathrm{W}$ Test & $\mathrm{H}(2, \mathrm{~N}=81)=.069 \mathrm{p}=.9661$ \\
\hline & Median test & Chi-Sq. $=.423 \mathrm{df}=2 \mathrm{p}=.8095$ \\
\hline \multirow{2}{*}{5} & $\mathrm{~K}-\mathrm{W}$ Test & $\mathrm{H}(2, \mathrm{~N}=81)=.813 \mathrm{p}=.6661$ \\
\hline & Median test & Chi-Sq. $=1.750 \mathrm{df}=2 \mathrm{p}=.4168$ \\
\hline \multirow{2}{*}{6} & $\mathrm{~K}-\mathrm{W}$ Test & $\mathrm{H}(2, \mathrm{~N}=81)=.690 \mathrm{p}=.7082$ \\
\hline & Median test & Chi-Sq. $=.352 \mathrm{df}=2 \mathrm{p}=.8384$ \\
\hline \multirow{2}{*}{7} & $\mathrm{~K}-\mathrm{W}$ Test & $\mathrm{H}(2, \mathrm{~N}=81)=1.689 \mathrm{p}=.4305$ \\
\hline & Median test & Chi-Sq. $=0.000 \mathrm{df}=2 \mathrm{p}=1.000$ \\
\hline \multirow{2}{*}{8} & $\mathrm{~K}-\mathrm{W}$ Test & $\mathrm{H}(2, \mathrm{~N}=81)=7.920 \mathrm{p}=.0191$ \\
\hline & Median test & Chi-Sq. $=8,290 \mathrm{df}=2 \mathrm{p}=.0158$ \\
\hline \multirow{2}{*}{9} & $\mathrm{~K}-\mathrm{W}$ Test & $\mathrm{H}(2, \mathrm{~N}=81)=1.144 \mathrm{p}=.5645$ \\
\hline & Median test & Chi-Sq. $=0.000 \mathrm{df}=2 \mathrm{p}=1.000$ \\
\hline
\end{tabular}

Note: F- factors

Source: own elaboration

Respondents evaluated following factors: 1 The age of technology, 2 Development of products, 3 Productivity, 4 The using of capability, 5 Unit production costs, 6 Order processing time, 7 The accuracy of order fulfillment, 8 The number of products' types, 9 Quality of products/ provided service. The calculated $p$-value of the analysis of intensity variance for stated factors is higher than 0.05 except factor 8 The number of products' types. The hypothesis $\mathrm{HO}_{2}$ is rejected only in case of factor 8 .

Step 5 consists of the summarization of obtained results and the proposal of the basic model of network entrepreneurial cooperation.

Modern organizations provide a substantial part of their business by different ways, which is influenced by various internal and external factors. Economic fluctuations, recessions and crises in the economic development equally affect large manufacturing corporations and also small and medium-sized (family) businesses. (Srovnalíková \& Pekarskiene, 2015). One of the possibilities how the business entities could cope with these challenges is the connection into purpose-specific form of the collaborative network. There are a lot of arguments and reasons for necessity of starting the collaborative network. The significant impact has the development which occurs in the surrounding entities'. The changes of surrounding's statement cause a new attitude of customers to provide products and services and put pressure on business entities to come to the innovation of their products or services. The offensive approach presents the creation of purpose oriented network cooperation. In the next part of paper we propose the model of this cooperation that is an interactive process consisting of 5 main steps presented in figure 4.

The basic prerequisite for the start of network cooperation is motive (1). Based on clearly motive, the entity evaluates and considers other reasons (2) by which the connection into the network is beneficial and effective in comparison with the innovation activities realized itself. Subsequently, the 


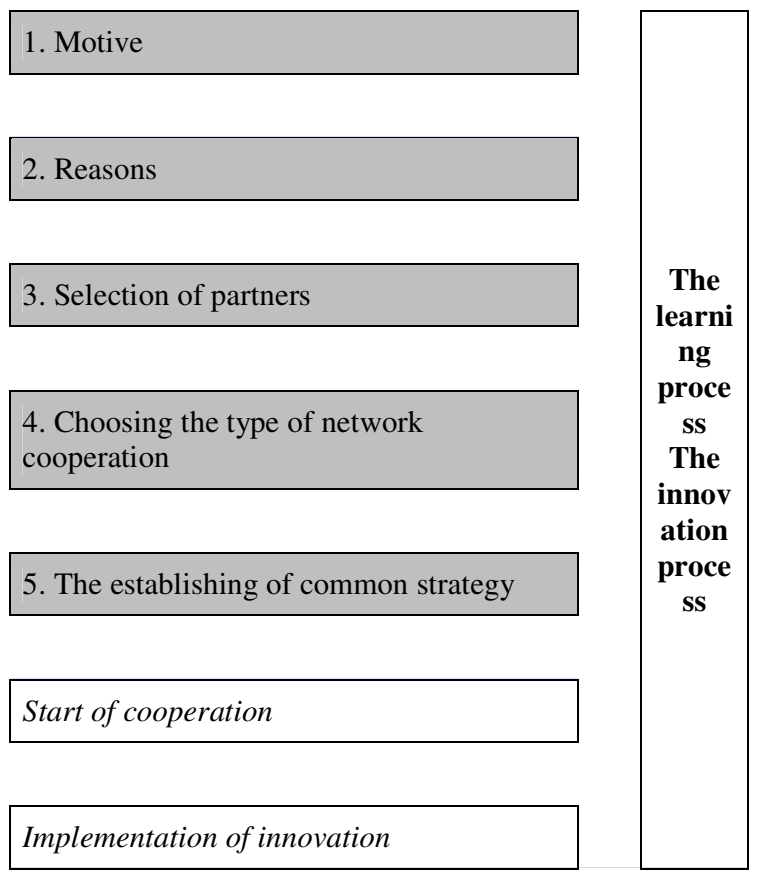

Source: own elaboration

Figure 4. The basic model of network entrepreneurial cooperation

entity investigates the potential partners and answers on questions concerning with the ability of innovative plan achievement, cooperation, capabilities and considers the possibilities of cooperation with other partners in relation to the requirements for cost, quality, delivery dates and forms, etc.. The next step (3) is the selection of partners. The important issue for future cooperation is the choice of the type of network cooperation (4). This depends on many factors such as: goals that entities plan to achieve, stated strategy, restrictions connected with networking, social links etc.

Next but not least is the establishing of the common strategy (5). Overall success is based on two basic conditions - the formulation of strategy and its successful implementation, both conditions must be fulfilled simultaneously. After the fulfillment of basic criteria and the determination of the overall strategy, there is launching the network cooperation and implementation of the innovation that is beneficial for all parties.

\section{CONCLUSION}

At present many business entities achieve the positive effects of its activities by following cooperation with other actors. In our study we focused on compilation of basic model of network entrepreneurial cooperation. For fulfillment of the main aim we realized several steps which are necessary for verification and fulfillment the basic conditions of modeling. According to results of the localization analysis we note, that in the Slovak Republic there are fulfilled basic conditions for network cooperation in the frame of individual branches. The results from the questionnaire survey pointed on the positives and negatives of network cooperation from the practical point of view and finally contributed to the proposal of main steps of the basic model of network entrepreneurial cooperation.

The main limitation of this research is based on the lack of statistical data. The Statistical Office of the Slovak Republic publishes data suitable for regional analysis with a time delay. Some of specific data are not available and some that could contribute to the findings of network cooperation are missing from the reason, that entrepreneurs are not obliged to give the data. Another limitation is distrust of stakeholders to participate in various form of network cooperation.

The results of this manuscript could contribute to the management practice in Slovakia in two ways. One way is to increasing of awareness for local stakeholder 
about main idea and utility of network cooperation and in second one lies on proposed methodology for creators of the regional policy to help identify the main aspects and possibilities for achieving of regional competitiveness through the network cooperation.

\section{Acknowledgement}

This paper was supported by the Ministry of Education, Science, Research of the Slovak Republic by this research projects VEGA 1/0381/13 and KEGA 001UCM4/2016.

\section{References}

Belás, J., Ključnikov, A., Vojtovič, S., \& Sobeková-Májková, M. (2015). Approach of the SME Entrepreneurs to Financial Risk Management in Relation to Gender and Level of Education, Economics and Sociology, 8 (4), 32-42.

Bujna, M., Kotus, M., \& Čičo, P. (2014). Risk management. Nitra: SPU.

Buleca, J. (2013). Support of innovation and entrepreneurship in Košice selfgoverning region. Acta Oeconomica Universitatis Selye, 2 (2), 47-56.

Fiala, P. (2008) Network economics. Praha: Professional Publishing, 225.

Grenčíková, A., Španková, J., \& Karbach, R. (2015). Current trends in enterprise empoyment policies in Slovak Republic.

\title{
ЕМПИРИЈСКИ РЕЗУЛТАТИ ПРЕДУЗЕТНИЧКЕ МРЕЖЕ: СТУДИЈА СЛУЧАЈА НА ПРИМЕРУ СЛОВАЧКЕ
}

\author{
Ladislav Mura, Katarína Havierniková, Renáta Machová
}

\section{Извод}

Изазови економског развоја различитих земања, у скорашњим декадама, су под утицајем процеса који су модификовали начине и форме за обављање пословања. Док је у прошлости значај стављан на величину компаније, у данашње време преовлађује значај учешћа компанија у различитим формама мрежа за сарадњу. Овај рад представља резултате емпиријског истраживања који је анализирао мала и средња предузећа, укључена у предузетничке мреже. Истраживање је спроведено током периода 2014.-2015. година, у оквиру научно истраживачких пројеката: "VEGA 1/0381/13" и "KEGA 001UCM-4/2016".

Основни циљ рада је да предложи основни модел сарадње предузетника у мрежама у условима Републике Словачке. Допринос овог рада је у навођењу основних корака које требају да предузму стејкхолдери, уколико желе да креирају успрешну мрежу. Парцијални циљеви рада су: евалуација квалитативних и квантитативних услова за умрежавање и опис активности које воде до стварања сарадње у мрежи. У анализи је коришћен селективни квантитативни метод (локализација коефицијената уз употребу БЦГ матрице). Квалитативни услови су процењени употребом упитника, који је идентификовао предлоге предузетника за укључивање пословања уз анализу адекватним статистичким алатима.

Кључне речи: Умрежавање, мрежа предузетника, иновативно предузетништво, мала и средња предузећа 
Actual problems of economics, 170 (8), 293301.

Habánik, J., \& Masárová, J. (2013). Changes in the sectoral structure of the Slovak economy. Social and Economic Revue, 11 (2), 64-73.

Chen, C.-P., Chien, C.-F., \& Lai, C.-T. (2013). Cluster policies and industry development in the Hsinchu Science Parka: A retrospective review after 30 years. Innovation: Management, Policy \& Practise. 15 (4), 416-436.

Kołakowski, T., Sobański, R. (2013). The development strategy of tourims cluster Dolnoslasky till 2020. Świdnica, 118 (In Slovak).

Krajnakova, E., Navikaite, A., \& Navickas, V. (2015). Paradigm Shift of Small and Medium-Sized Enterprises Competitive Advantage to Management of Customer Satisfaction. Engineering Economics, 26 (3), 327-332.

Loučanová, E., \& Zaušková, A. (2007). Identification the cluster woodprocesing sector in the Slovak republic. Intercathedra, 23, 61-66.

Okreglická, M., Mynarzová, M., \& Kaňa, R. (2015). Business Process Maturity in Small and Medium Sized Enterprises. Polish Journal of Management Studies, 12 (1), 121131.

Srovnalíková, P., Pekarskiene, I. (2015) The conditions and advantages of family business. In Social and Economic Revue, 13 (03), 31-38.

Súbertová, E. (2015). Dynamics and Branch Structure of Self-employed Persons and Limited Companies in the Slovak Republic. MANEKO, 7 (1), 122-131.

Tidd, J., Bessant, J., \& Pavitt, K. (2005). Managing Innovation: Integrating Technological, Market and Organizational Change. 3rd edition, John Wiley \& Sons,
Ltd, Chichester, West Sussex, England.

Vojtovic, S., \& Krajňakova, E. (2013).

Trends in Economic Growth and Unemployment in Slovakia. International Conference on Education, Management (ICEMSS-13), Publisher: Paris: Atlantis Press, 188-191.

Waldorf, B., Cordes, S.M., Kumar, I., Nolan, C.E., Conover, J., \& Rogers, C. (2006). Locational Patterns of Industry Clusters in Indiana. In: MCRSA/IMPLAN Conference, Indianopolis, Indiana, 1-69.

Zaušková, A. (2010). Clusters - a tool for enhancing innovation performance and the competitiveness of regions. Communication Today, 1 (1), 43 - 64.

Živković, Ž., Mihajlović, I., \& Prvulović, S. (2009). Developing Motivation Model as a Strategy for HRM in Small Enterprises under Transitional Economy. Serbian Journal of Management, 4 (1), 1-27. 